\title{
SERUM LIPID AND LIPOPROTEIN EVALUATION IN PATIENTS WTTH ISCHAEMIC HEART DISEAST
}

\author{
*T.K. AMARESHWAR SINGH., **A. RAJAGOPALA RAIU., AND \\ *O.S. REDDI
} * School of Biotechnology, Jawaharlal Nehru Technological University, Mahaveer Marg,
Hyderabad-500028, India.

* Depantment of Cardiology, Nizam's Institute of Medical Sciences Puniagutta, Hyderabad - 500482, India.
(Date of receipt
: 08 August 1988)
(Date of accepiance
: 27 August 1991)

\begin{abstract}
Serum lipid profiles were analysed in the study population comprising of 330 healthy persons and 166 patients with ischaemic heart disease. Comparison amongst the study population was done in order to find out the frequency of hyperlipidemias in relation to age and scx, and the susceptibility to this disease was assessed in terms of low density lipoprotein and high density lipoprotein concentrations. The present study strengthens the importance of clevated levels of serum cholesterol, iniglycerides, beta-lipoprotein, prebeta-lipoprotein, and low density lipoprotein cholesterol., and a reduced concentration of alpha-lipoprotein and high density lipoprotein cholesterol as risk factors for ischaemic heart disease.
\end{abstract}

\section{Introduction}

Ischaemic heart disease (IHD) has become an alarming public health problem. Hyperlipidemia is a common finding in patients with IHD. There is a strong evidence that the risk for IHD rises with increasing levels of plasma total cholesterol. ${ }^{28}$ Worldwide epidemiological surveys consistently support this relation. ${ }^{24,34,37}$ Three major studies - Framingham Heart Study, ${ }^{23}$ the Pooling Project, ${ }^{31}$ and an Israeli Prospective Study ${ }^{12}$ are representative of most surveys. The relation between plasma triglyceride levels and coronary risk has been a subject of dispute. A positive correlation has been noted in some studies, ${ }^{14,17}$ but the pathogenic significance of the variability in triglyceride levels within the normal range remains disputed.

The overall incidence of abnormal lipoproteins was more in myocardial infarcts than in patients with angina. These patients showed significantly lower values of high density lipoprotein (HDL) as compared to the healthy controls. Jenkins et al. ${ }^{22}$ emphasise that the concentration of various lipoproteins were directly related to the severity of coronary atherosclerosis, HDL having an apparent retarding effect.

Concentration of low density lipoprotein cholesterol (LDLc) are positively correlated with IHD risk, while high density lipoprotein cholesterol (HDLc) is correlated inversely. This inverse association has been well documented by the Framingham Heart Study. ${ }^{16}$ The present work has been aimed to study the serum lipid profile of the study population comprising of controls and survivors of IHD, and 
corparison amongst the study population in order to find oxt the frequency of hyperipionemias in relation to age and sex.

\section{Materín}

A total of 330 healthy persons comprising of 215 males and 115 fenales were selected as controls for the present study. Subjects, born of healthy parents and having healthy brothers and sisters, with a nomal ECG and with no known manifestation of any disease or evidence of ady metabolic disease or history of cardiovascular disease, were selected as controls.

166 MMD paticnts from Hyderabad and meighbouring places and hokn middle to afturent class of warious age grows and of either sex were investigatch for the serum cholesterol, triglycerides, low density lpoprotein (LDL), very low density lipoprotein (VLDL), high densiry lipoprotein (HOL), low deasity lipoprotein cholesterol and high density lipoprocein cholesterol concentrations. These invescigatons were carried out between the second to the enghth day following the onset of the disease. These cases were selected from the Cardiology Unit of the Nizam's Institute of Medical Sciences, Wyderabad. Out of these, 112 patients suffered from acute myocardial infarction and the balance 54 suffered from angina pectoris. A minimum of two of the following criteria were taken into account for the diagnosis of myocardial infarction (MV): typical history, typical ECG chazges, or raised SGOT or LDH levels. The diagnosis of angina pectoris ( $A$ ) was based on a typical history with confirmatory ECG changes. The controls as well as the patients were studied under the following age groups: $30-39$ years, $40-49$ years, $50-59$ years and $60-69$ years.

Serum samples: Brood samples were collected with the consent and awareness of the individuals involved. These samples were arawn after the subjects had fasted for 12-14 wours and berween the second to the eighth day after the oruset of the heart uisease. Blood was allowed to clot in a test tube at room temperature for 2 hours. The clot was gently freed from the wall of the test tube. The red cells were sedinemed by centrifugation at 3000 rpm for 10 minutes. The serum was subsequently stored at $4^{\circ} \mathrm{C}$ and analysed the same day the blood is chawn.

Serum total cholesterol was estimated with the modified method of Zlatkis, Zak and Boyle ${ }^{39}$ as described by Henly. ${ }^{21}$ Triglycerides were estimated by the modified method of Fetcher ${ }^{10}$ as described by Foster and Dunn. 11 Lipoproteins were separated by clectrophoresis with the method of Noble. ${ }^{29}$ LDLc was estimated with the method of Henly after precipitating LDL with the method of Burstein and Samaille. Serum was added to heparin/ $\mathrm{CaCl}_{2}$, cyclomixed and set aside for 15 minutes at room temperature. The tube was then spun at $3000 \mathrm{rpm}$. The supernatant was carefully discarded. The tube was then placed inverted on a filter paper for 10 minutes. Residual supernatant was removed with filter paper. Cholesterol was extracted from the residue by the addition of ferric chloride acetic acid reagent. Sulphuric acid is then added, cyclomixed carefully and set aside for colour development. The colour developed was read in a colorimeter. Blank and standard were also run simultaneousiy. HDLc was estimated with the method of Henly ${ }^{21}$ after 
removing HDL with the method of Allen et al. ${ }^{1}$ Polyethylene gilycol was added to the serum, mixed well and set aside for 10 minutes. The tube was then spun at 3000 rpm. To the supernatant, ferric chloride acetic acid reagent was added, mixed well and set aside for 15 minutes to precipitate proteins and then centrifuged. The supernatant was transferred into another rube and sulphuric acid was added to it, mixed well, ser aside for 20 minutes and the colour developed was read colorimetrically. Blank and standard were run simultaneousily.

The significance between the means of the lipid levels in the controls and the survivors, and between the subgroups was tested by the test. Any calculated value which was greater than the tabulated value at $5 \%$ was regardea as significant implying significant differences between the means at that probability level.

\section{Resulis}

The cholesterol and triglyceride contents of serum were measured in a series of maic and female IHD patients. Variations with age were found to exist in all the groups. The cholesterol and triglyceride contents of serum in controls and in IHD cases and the significance of the differences as compared with the controls are presented in Table 1. In males, the mean concentrations of both lipids were greater than control values, particularly in the younger age groups, and the percentage of $1 H D$ patients with abnormal values in the older age groups steadily decreased. Among the controls, the cholesterol level increased with each successive decade, the peak incidence being expressed in the 50-59 age group. Serum triglyceride expressed its optimal values in the fifth as well as in the seventh decades. The maximum values of these two lipids in the MI group occurred in the younger age groups and thereafter the levels rended to decrease with increasing age. The condition was similar in the AP group too. In females, the mean serum cocentrations of these two lipid fractions in controls was higher in the 40 years age group and above, i.e. post-menopausal age. High levels of cholesterol was found in the age group 40-49 years in both the MI and AP patients. In the AP group, the serum triglycerides were significantly high in the seventh decade.

Table 2 indicates the serum lipoprotein electrophoretic values controls and in IHD patients. These values represent the mean relative percentage of lipoprotein bands. LDL and VLDL levels were high and HDL low in the high-risk group when compared to the controls. The data corresponding to the statistical significance of the differences in mean lipoprotein values in the IHD subgroups as compared with the controls and with each other is presented in Table 2[a]. The WHO extension of the original five-type classification system was used and the patients were allocated to one of the six types. 
T.K. Amareshwar Singh et al.

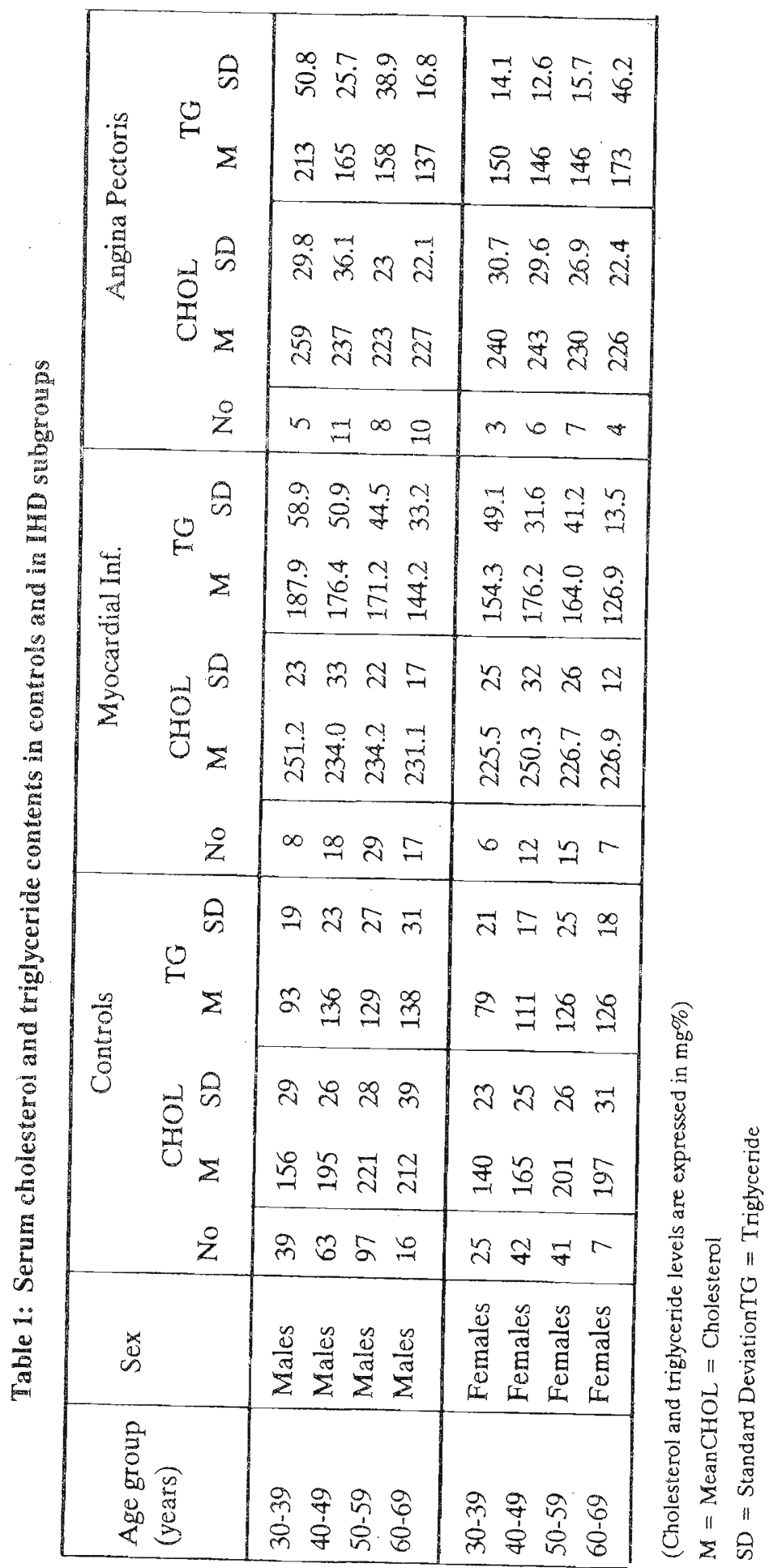




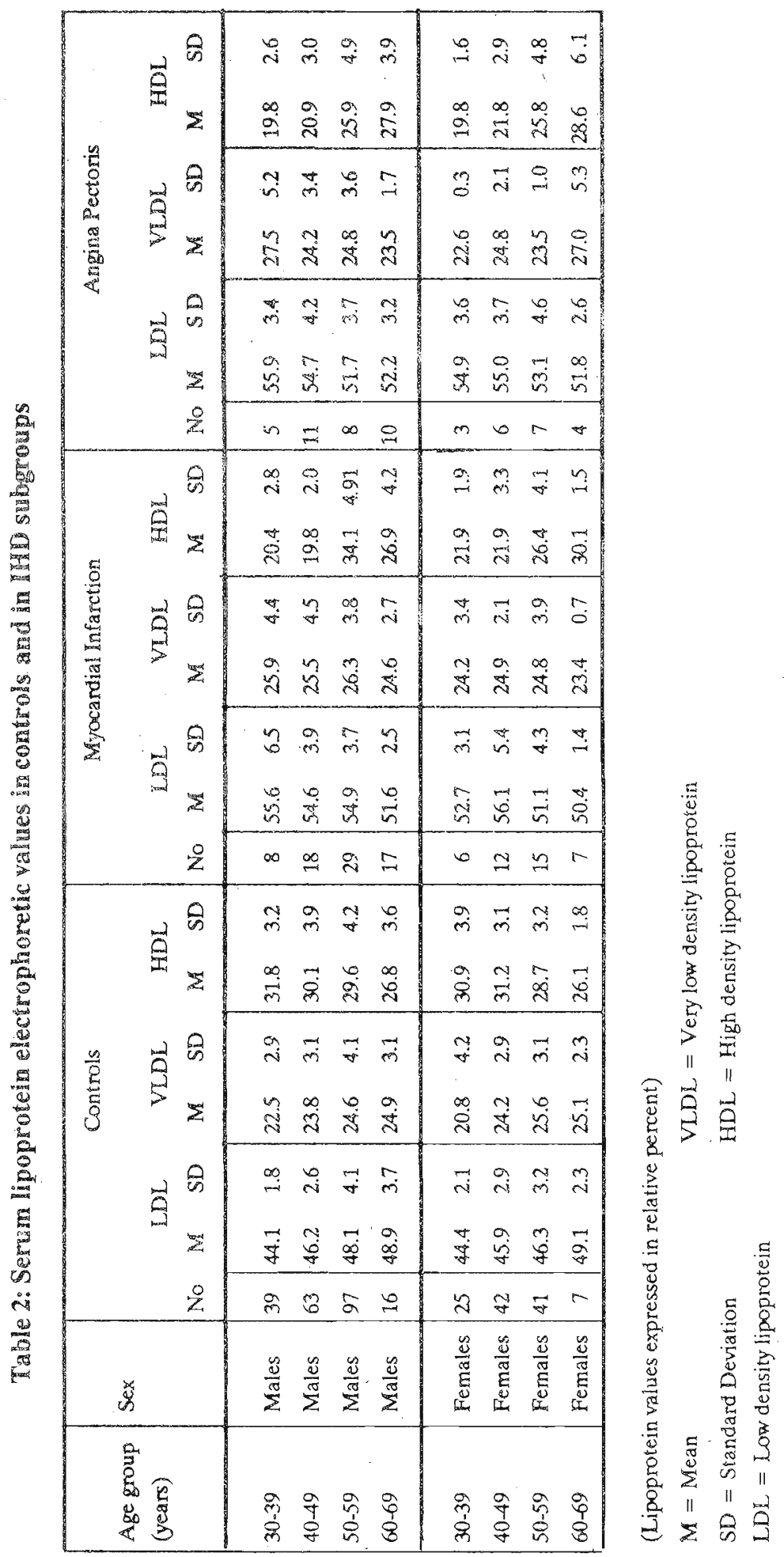




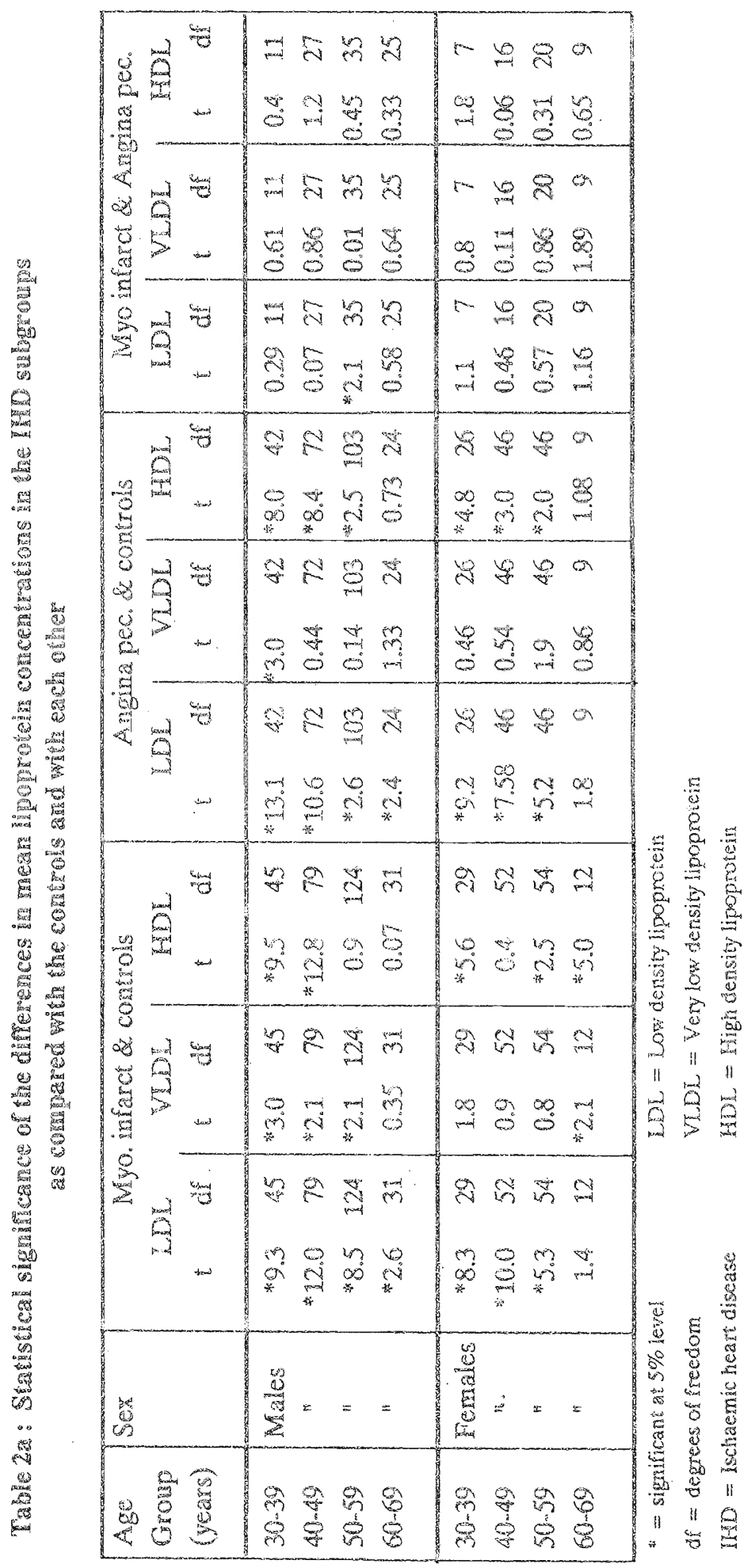


The frequency of the different types of lipoproteinemias in IHD patients is presented in table 3 . The commonest abnormality was type Ila, which was observed ina $31(18.6 \%)$ cases. The next frequent condition was type IV, seen in $19(11.5 \%)$ cases, followed by type IIb observed in $6(3.6 \%)$ cases.

Table 3:Frechency of the different types of lipoproteinemias in $1 H D$ patients

\begin{tabular}{|c|c|c|c|c|c|}
\hline \multirow{2}{*}{$\begin{array}{l}\text { Manifestation } \\
\text { of IHD }\end{array}$} & \multirow{2}{*}{$\begin{array}{l}\text { Type of } \\
\text { lipopro- } \\
\text { teinemia }\end{array}$} & \multirow{2}{*}{$\begin{array}{l}\text { Males } \\
\text { (No.) }\end{array}$} & \multirow{2}{*}{$\begin{array}{l}\text { Females } \\
\text { (No.) }\end{array}$} & \multicolumn{2}{|c|}{ Frequency } \\
\hline & & & & Total No. & Percentage \\
\hline \multirow{3}{*}{$\begin{array}{l}\text { Myocardial } \\
\text { infarction }\end{array}$} & Ia & 12 & 6 & 18 & 10.8 \\
\hline & $\mathrm{Mb}$ & 3 & 2 & 5 & 3.0 \\
\hline & IV & 11 & 3 & 14 & 8.5 \\
\hline \multirow[t]{4}{*}{ Angina pectoris } & IIa & 8 & 5 & 13 & 7.8 \\
\hline & $\mathrm{Mb}$ & 1 & nil & 1 & 0.6 \\
\hline & IV & 4 & 1 & 5 & 3.0 \\
\hline & & & TOTAL & 56 & 33.7 \\
\hline
\end{tabular}

$I H D=$ Ischaemic heart disease

Total number of IHD cases studied $=166$

Hyperlipidemic IHD cases $=56$

The mean levels of LDLc and HDLc in controls and in the IHD survivors are presented in figures 1 and 2 respectively.

56 of the 166 IHD patients studied were hyperlipidemic. Not all were hyperlipidemic. Table 4 shows the frequency of hyperlipidemic states in IHD patients. The highest frequency of hyperlipidemia was observed in both sexes in the 40-49 years age group. In the hyperlipidemic IHD patients studied it was observed that their serum HDLc leveis were low and LDLc levels were high when compared to the controls. The frequency of hyperlipidemias in relation to age and sex in IHD survivors is presented in figure 3. 


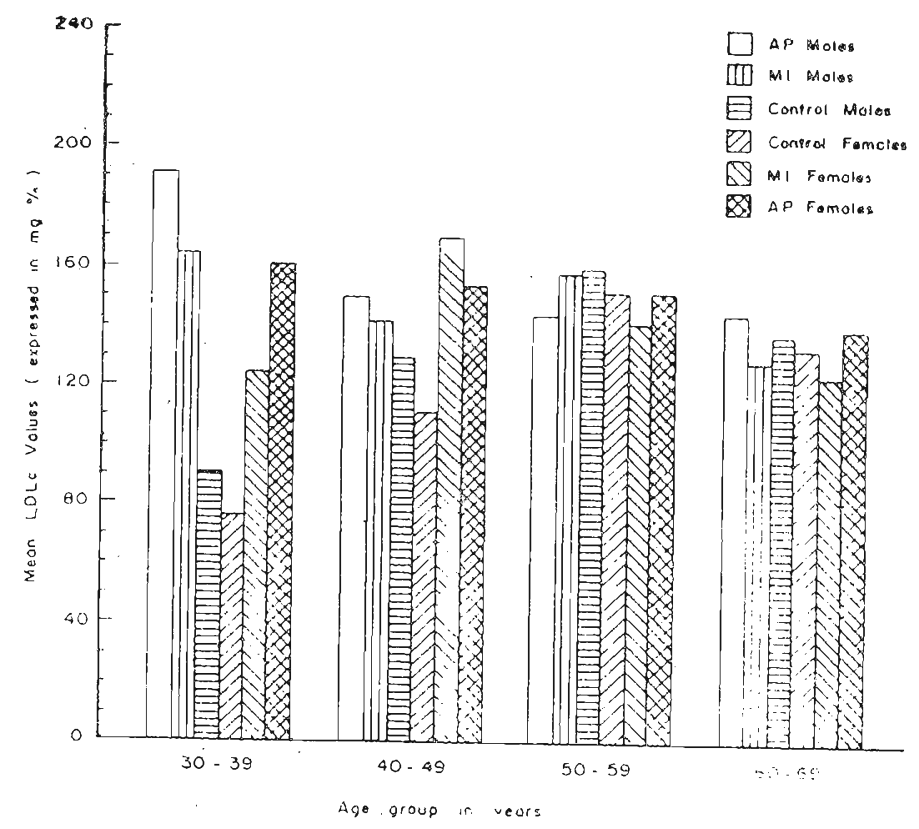

Figure 1: Mean LDL - Cholesterol Values in Controls and in Survivors.

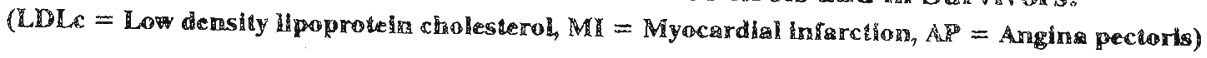

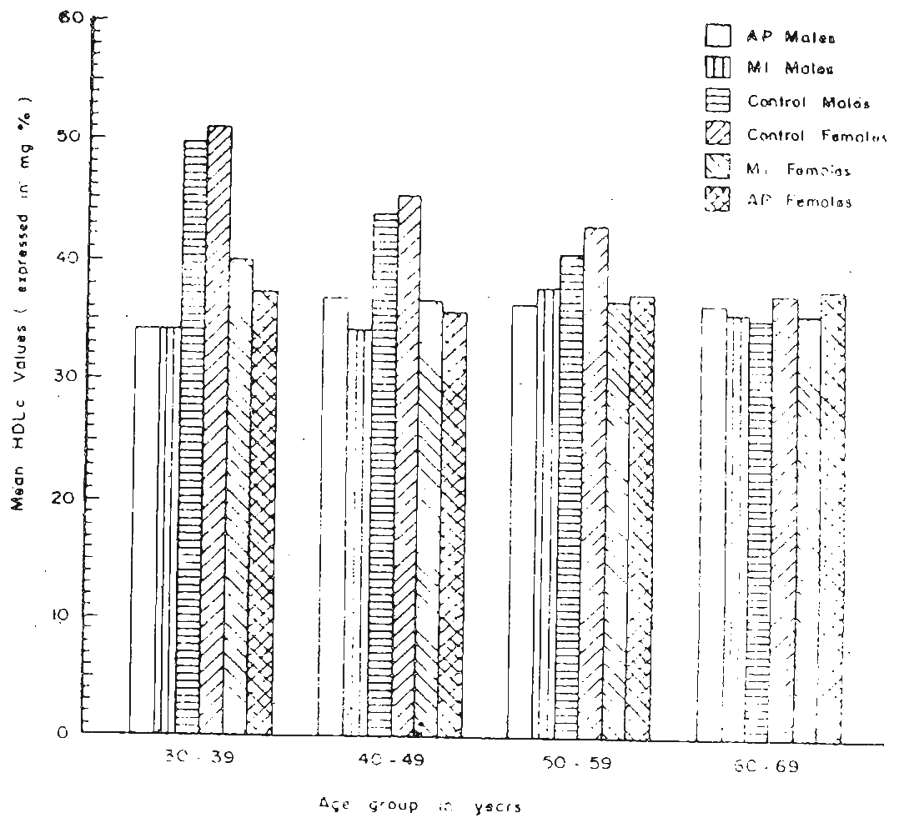

Figure 2: Mean HDL - Cholesterol Values in Controls and in Survivors. (HDLc = Wiligh density lipoprotein cholesterol, MI = Myocardial infarction), AP = Angina pectoris) 


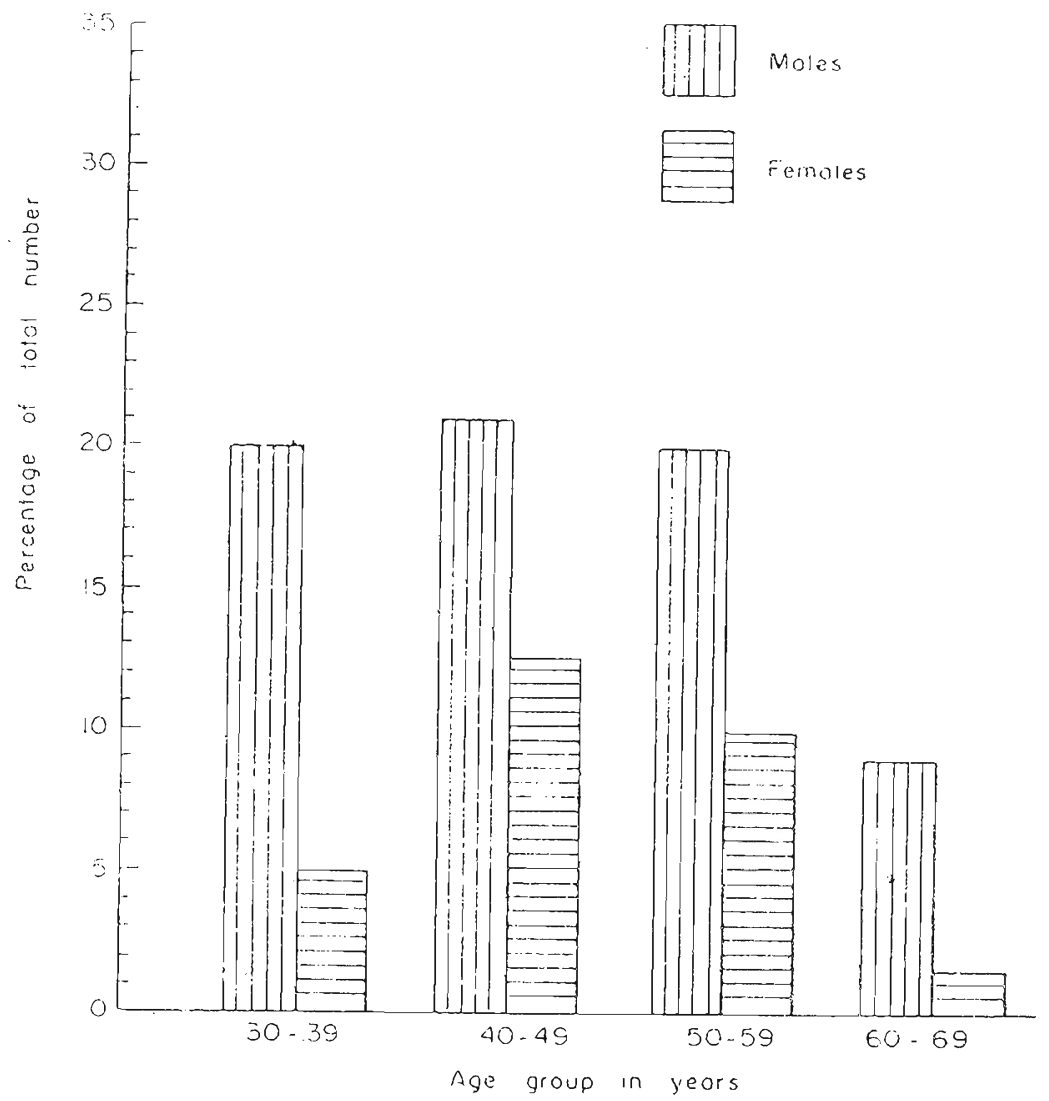

Figure 3: Frequency of hyperlipidaemias in relation to age and sex in Survivors.

Table 4: Frequency of hyperlipidemic states in IHD patients

\begin{tabular}{lccccc}
\hline $\begin{array}{l}\text { Manifesta- } \\
\text { tion of } \\
\text { IHD }\end{array}$ & Sex & No. & $\begin{array}{l}\text { Hypercholes- } \\
\text { terolemia } \\
\text { (per cent) }\end{array}$ & $\begin{array}{l}\text { Hypertrigly- } \\
\text { ceridemia } \\
\text { (per cent) }\end{array}$ & $\begin{array}{l}\text { Combined } \\
\text { hyperli- } \\
\text { pidemia } \\
\text { (per cent) }\end{array}$ \\
\hline $\begin{array}{l}\text { Mycocardial } \\
\text { infarction }\end{array}$ & Males & 26 & 46 & 42 & 11.5 \\
$\begin{array}{l}\text { Angina } \\
\text { pectoris }\end{array}$ & Males & 13 & 53 & 30 & 7.0 \\
\hline $\begin{array}{l}\text { Myocardial } \\
\text { infarction }\end{array}$ & Females & 11 & 54 & 27 & 18 \\
$\begin{array}{l}\text { Angina } \\
\text { pectoris }\end{array}$ & Females & 6 & 83 & 16 & nil \\
\hline
\end{tabular}




\section{Discussion}

Coronary atherosclerosis and its clinical sequelae represent a multicausal process of enormous magnitude. Lipids and lipoproteins are implicated in coronary atherosclerosis and its major symptomatic manifestations. Hyperlipidemic condition is a frequent finding in $r H D$ patients.

The reported frequency of lipid abnormalities in IHD is variable. Tn the present study, hypercholesterolemia was found to be predominant over hypertriglyceridemia and combined hyperlipidemia. This great preponderance of raised cholesterol was also noted by Gustafson et al. ${ }^{19}$ and Leren et al. ${ }^{26}$ This may or may not be a universal finding, but comparable findings have also been reported by Goldstein et al. ${ }^{14}$

The significance of hypertriglyceridemia in IHD has long been a subject of coniroversy. Increased triglyceride Icvels were intepreted to be an independent risk factor for IHD by Carlson et al. ${ }^{6}$, but Brown et al. ${ }^{3}$ contradicted this point of view. The present study does not resolve the issue of whether hypertriglyceridemia may be additive to the unarguable role of hypercholesterolemia. There are no grounds for the assumption that one or other form of hyperlipidemia is uniquely associated with atherosclerotic heart disease.

Serum cholesterol and triglyceride levels were higher in the survivors of IHD when compared to the controls. Elevated levels of cholesterol confirm the reports of Chaudhari et al.. ${ }^{8}$ Rise in the levels of triglyceride in survivors was similar to the
reports of Schroff et al. ${ }^{35}$ and Chaudhari et al..

The overall incidence of abnormal lipoprotein was more in $M$ than in angina. Sharma et al. ${ }^{36}$ also reported higher incidence of abnormal lipoproteinemic states in MI as compared to the AP group. Jenkins et al. ${ }^{22}$ observed a strong inverse association between the concentration of HDL and coronary atherosclerosis score. They also emphasised that concentration of various lipoproteins were directly related to the severity of coronary atherosclerosis, HDL having an apparent retarding effect.

LDLc levels were elevated in IHD patients when compared to the controls This finding confirms the report of Rao et al.. ${ }^{32}$ Decreased levels of HDLc in IHD was reported by many clinical studies (Carlson et al., and Brunner et al.). ${ }^{7,4}$ The present study confirms the finding of Western studies that the presence of IHD is correlated negatively with HDLc and positively with LDLc levels (Enger et al.,

Hypercholesterolemia was found to be predominant over hypertriglyceridemia and combined hyperlipidemia. In the present study hyperlipidemia was found in $33.7 \%$ of the 166 IHD patients. Patterson and Slack ${ }^{30}$ reported the frequency of hyperlipidemias in MI patients as $25 \%$. Goldstein et al. ${ }^{15}$ reported the frequency of hypercholesterolemia, hypertriglyceridemia and combined hyperlipidemia as $7.6 \%$, $15.6 \%$ and $7.8 \%$ respectively. Kumar et al. ${ }^{25}$ reported the frequency of hypercholesterolemia as $18 \%$ in the MI patients. They studied lipid profiles in male 
subjects only. Harshwardhan et al. ${ }^{20}$ reported the frequency of hypercholesterolemia in MI patients as $50 \%$ and combined hyperlipidemia as $8.3 \%$. Frequency of hypertriglyceridemia was not reported in most of the Indian studies. The frequency of combined hyperlipidemia was low as compared to the studies of Harshwardhan et al.. ${ }^{20}$

Gupta et al. ${ }^{18}$ reported the frequucncy of types IIa, IIb and IV hyperlipoproteinemia in 20 cases of MI as $15 \%, 10 \%$ and $25 \%$ respectively. Lewis et al. ${ }^{27}$ found types $\mathrm{II}$ a, IIb and IV as $14 \%, 18 \%$ and $31 \%$ respectively in $143 \mathrm{IHD}$ patients. The frequency of IIa was high and types IIb and IV were low when compared to the reports of Gupta et al. ${ }^{18}$ and Lewis et al.. ${ }^{27}$

Future prospects for further risk definition will involve the protein constituents of the lipoproteins. Apo-B has a central role in the absorption of cholesterol and triglyceride and of their transport in the body. The plasma levels of $L p(a)$ and apo-B are under strong genetic control, and increased circulating apo-B and $L p(a)$ concentrations are additive as risk factors for premature IHD (Armstrong et al., Rhoads et al., and Utermann et al.). 2,33,38

\section{Acknowledgement}

We thank all the patients and the normal subjects for their co-opcration in carrying out the present study. The study was supported by grants from the Council of Scientific and Industrial Research, New Delhi.

\section{References}

1. ALLEN, J.K., HENSLEY, W.J., NICHOLLS, A.V. \& WHITFIELD, J.B. (1979) Clin. Chem. 25: 325-327.

2. ARMSTRONG, V.W., CREMER, P., EBERLE, E. et al. (1986) Ainerosclerosis $62: 249-257$.

3. BROWN, D.F., KINCH, S.H. \& DOXLE, S.T. (1972) New Engl. J.Med. 273: 947-952.

4. BRUNNER, D., WEISBORT, I., LOEBL, K. et al . (1979) Atherosclerosis 33 : 9.

5. BURSTEIN, M. \& SAMAILLE, J. (1960) Clin. Chim. Acta. 5 : 609.

6. CARLSON, L.A. \& BOTTIGER, L.E. (1972) Lancet 1:865-868.

7. CARLSON, L.A. \& ERICSSON, M (1975) Atherosclerosis 21 : 435.

8. CHAUDHARI, S. \& SUNDRAM, K.R. (1977) Thromb. Res. 11 : 163.

9. ENGER, S.C. HJERMANN, I. FOSS, O.P. et al. (1979) Artery 5 : 170.

10. FLETCHER, M.J. (1968) Clin. Chim. Acta. 22 : 393-397.

11. FOSTER, L.B. \& DUNN, R.T. (1973) Clin. Chim. 19 : 338-340.

12. GOLDBOURT, U., HOLTZMAN, E. \& NEUFELD, H.N. (1985) Br. Med.. . $290: 1239-1243$. 
13. GOLDBOURT, U. \& MEDALIE, J.H. (1979) Amer. J. Epidemio. 1 M9: 296.

14. GOLDSTEN, Y.2., HAZZARD, W.R., SCHROTT, H.G. et ä. (1973) J. Chr. rovest. 32 : 1533-1543.

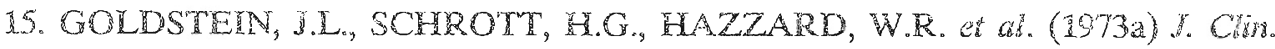
invest. 52 : 1533 .

16. GORDON, T. KANNELL, W.B., CASTELLI, W.P. \& DAWBER, I.R. (1981) Arch. Intem. Nea. 141: 1128-1131.

17. GOMOA, A.M., GORRY, A., ThOMPSON, I.R. et al. (1977) Cromation 56: $875-833$.

18. GUMTA, R.C., SHARMA, S.K. \& GUPTA, N.C. (1980) Ind. HeGr y 32:296.

19. GUSTAFSON,A., ELMFELDT, D., WWLELMSEI, L. er al. (1972) Cix culatom 粕: $709-716$.

20. MARSHWARDHAN, J.S. \& GUPTA, M.P. (1980) Ind Ferm, $72: 75$.

21. HENLY, A.A. (1957) Analyst 896287.

22. JENKWNS, F.HARPER, R.W. \& NESTEL, P.J. (1978) Br. Med.J.2.388-391.

23. WANNEL, W. B., CASTELLI, W. GORDON, W.\&MWAMARA, R. (1971) Arr. Intem. Med. 74:1-12.

24. KOZAREVIC, D., PIRC, B., RACIC, Z. et al. (1976) Am. J. Epidemiol. 19A: 133-140.

25. KUMAR, M., CHAKRAVARTI, R.N., SINGH, A. \& WAHI, P.L. (1976) Atheroscierosis $24: 355$

26. LEREN, P. \& HAABREKKE, O. (1971) Acta. Med. Scand. 189: 505-509.

27. LEWIS, B., CHAIT, A., OAKLEY, C.M.O. et al. (1974a) Br. Med. J. 3: 489.

28. NEATON, Y.D., KULLER, L.H., WENTWORTH, D. \&. BORHANI, N.O. (1984) Ans. Heart. J. $108: 759-769$.

29. NOBLE, R.P. (1968) J. Lipid. Res. 9:693-700.

30. PATTERSON, D. \& SLACK, J. (1972) Lancet. 1: 393.

31. Pooling Project Research Group (1978) J. Chronic. Dis. 31: 201-306.

32. RAO,C.R. \&SUBBA RAO, A. (1975) Antery 1: 428.

33. RHOADS, G.G., DAHLEN, G., BERK, K. et al. (1986) J. Amer. Med. Assn .256. 2540-2544.

34. ROSE, G. REID, D.D. HAMILTON, P.S. et al (1977) Lancet 1: 105-109

35. SCHROFF, K.P., SHAH, S., GOYAL, B.K. \& CHAKRAVARTHY, B.R. (1973) Ind. Heart. J. 25: 122.

36. SHARMA, S.K. \& MADHOK, R.K. (1978) Abstract published in the proceedings of the VIII World Congress of Cardiology held in Tokyo. 
37. TIBBLIN, G., WILHELMSEN, L. \& WERKO, L. (1975) Am. J. Cardiol. 35 : 514-522.

38. UTERMANN, G., KRAFT, H.G., MENZEL, H.J. et al. (1988) Hum. Genet. 78 : 41-46.

39. ZLATKIS, A., ZAK, B. \& BOYLE, A.J. (1953) J. Lab. Clin. Med. 41 : 486-492. 